\title{
DUALISME PENYELESAIAN SENGKETA KONSUMEN DI SEKTOR JASA KEUANGAN
}

\author{
Andryawan ${ }^{1}$ \\ ${ }^{1}$ Fakultas Hukum, Universitas Tarumanagara Jakarta \\ Email: andryawan@fh.untar.ac.id
}

\begin{abstract}
The estabilishment of alternative dispute settlement institutions in the financial service sector by financial services authorithy as if it wants to compete with the existence of consumer dispute settlement agency. The estabilishment institutions of alternative dispute settlement in the financial service sector on the basic of financial service authority regulatory law number 1 year 2014 on the financial service authority, while consumer dispute settlement agency formed by the law number 8 year 1999. Verdict generated by these two institutions are final and binding, however against the verdict institutions of alternative dispute settlement in the financial service sector cannot be impelemnted if the consumer does not accept the verdict, giving rise to the possibility for financial service businesses to submit district court (of justice). Another case with verdict of the consumer dispute settlement agency it can be objected in district court (of justice) by one of the parties does not accept the verdict. The prosecuting authority (competence) of the institutions of alternative dispute resolution financial service sector and consumer dispute resolution has not been regulation, so that dualism in handling consumer disputes settlement agency. This is evidenced by the many disputes between the consumer banking or non-banking and non-financial services businesses were marked by consumer dispute settlement agency. Therefore need for strict regulation regarding the authority or competence of an absolute judge of these two institutions and needs for improvement of the legislation to get around this legal weaknes shortcomings.
\end{abstract}

Keywords: consumer, dispute, financial service sector.

\section{PENDAHULUAN}

Seiring dengan semakin berkembangnya dunia bisnis/usaha dewasa ini, tentu secara langsung menimbulkan dampak pula bagi konsumen. Perkembangan dunia bisnis yang berorientasi pada kegiatan untuk mencari keuntungan (profit) harus tetap dilaksanakan dengan memperhatikan hak-hak konsumen.

Mengenai instrumen Hukum Perlindungan Konsumen terdapat dalam Undang-Undang Nomor 8 Tahun 1999 tentang Perlindungan Konsumen (UUPK), yang telah disahkan dan diundangkan sejak tanggal 20 April 1999. Di dalam Pasal 1 Angka 2 UUPK, konsumen dirumuskan sebagai "Setiap orang pemakai barang dan/atau jasa yang tersedia dalam masyarakat, baik bagi kepentingan diri sendiri, keluarga, orang lain, maupun makhluk hidup lain dan tidak untuk diperdagangkan."

Dengan diberlakukannya UUPK, maka negara secara langsung telah menyadari bahwa hak konsumen secara hukum harus dilindungi dari tindakan-tindakan pelaku usaha dalam menjalankan kegiatan bisnis yang dapat berpotensi merugikan konsumen. Hal inilah yang menjadi momentum awal dari ditegakannya Hukum Perlindungan Konsumen.

UUPK tidak hanya mengatur mengenai hak dan kewajiban konsumen, tetapi juga hak dan kewajiban pelaku usaha. Rumusan pelaku usaha terdapat dalam Pasal 1 Angka 3 UUPK, yaitu "Setiap orang perseorangan atau badan usaha, baik yang berbentuk badan hukum maupun bukan badan hukum yang didirikan dan berkedudukan atau melakukan kegiatan dalam wilayah hukum negara Republik Indonesia, baik sendiri maupun bersama-sama melalui perjanjian menyelenggarakan kegiatan usaha dalam berbagai bidang ekonomi." 
Salah satu pelaku usaha yang banyak berkembang dewasa ini adalah pelaku usaha jasa keuangan (baik perbankan maupun non perbankan). Dalam lembaga keuangan non-bank, salah satunya adalah lembaga pembiayaan konsumen. Kegiatan usaha ini lahir dari adanya kebutuhan dana bagi banyak orang, dan di lain pihak juga ada banyak badan hukum yang memiliki kelebihan dana untuk disalurkan kepada masyarakat dengan tujuan untuk mendapatkan keuntungan. Sehingga dana yang berlebihan tersebut perlu diinvestasikan dengan cara yang paling menguntungkan secara ekonomis ataupun sosial. Kumpulan orang-orang/lembaga/badan hukum inilah yang kemudian disebut sebagai Pelaku Usaha Jasa Keuangan (PUJK).

Keberadaan PUJK ini diawasi dan diatur oleh Otoritas Jasa Keuangan (OJK). OJK merupakan sebuah lembaga pengawas jasa keuangan seperti industri perbankan, pasar modal, reksadana, perusahaan pembiayaan, dana pensiun, dan asuransi. OJK sendiri dibentuk berdasarkan UndangUndang Nomor 21 Tahun 2011. Dengan dibentuknya OJK, maka seluruh perizinan, pengaturan, dan pengawasan terhadap kegiatan usaha di bidang perbankan maupun non perbankan sepenuhnya berada di bawah OJK (yang sebelumnya berada di bawah Menteri Keuangan).

OJK adalah lembaga yang independen dan bebas dari campur tangan pihak lain, yang mempunyai fungsi, tugas, dan wewenang pengaturan, pengawasan, pemeriksaan, dan penyidikan. ${ }^{1}$ Dibentuknya OJK bertujuan agar keseluruhan kegiatan di dalam sektor jasa keuangan dapat terselenggara secara teratur, adil, transparan, dan akuntabel; mampu mewujudkan sistem keuangan yang tumbuh secara berkelanjutan dan stabil; serta mampu melindungi kepentingan konsumen dan masyarakat.

Kedudukan konsumen dan pelaku usaha cenderung dirasa tidak seimbang. Hal ini dikarenakan posisi pelaku usaha yang lebih kuat dan masih rendahnya tingkat kesadaran konsumen. Kondisi ini sering kali menyebabkan pelaku usaha mengabaikan hak-hak konsumen (melanggar hak konsumen).

Ketidakseimbangan tersebut dapat memicu terjadinya sengketa antara kedua belah pihak. Oleh karena itu, dengan diundangkannya UUPK diharapkan dapat menjadi payung hukum yang dapat melindungi hak-hak konsumen dari tindakan pelaku usaha. Diundangkannya UUPK diikuti dengan dibentuklah Badan Penyelesaian Sengketa Konsumen (BPSK) sebagai badan/lembaga publik yang mempunyai tugas dan wewenang antara lain melaksanakan penanganan dan penyelesaian sengketa konsumen melalui konsiliasi, mediasi, dan arbitrase.

Konsumen yang merasa dirugikan/dilanggar haknya dapat mengajukan upaya hukum (dengan cara menggugat) pelaku usaha, baik secara litigasi (melalui pengadilan) maupun non litigasi (di luar pengadilan). Penyelesaian sengketa konsumen secara non litigasi dapat ditempuh melalui BPSK. Pelaksanaan tugas dan wewenang BPSK berpedoman pada Keputusan Menteri Perindustrian dan Perdagangan Nomor 350 Tahun 2001 tentang Pelaksanaan Tugas dan Wewenang BPSK.

Eksistensi BPSK ini semakin teruji seiring dengan berjalannya waktu. Hal ini dibuktikan dengan banyaknya konsumen yang menggugat pelaku usaha ke BPSK apabila terjadi pelanggaran hak konsumen (sengketa). Fenomena ini juga menunjukkan bahwa semakin tingginya kesadaran konsumen untuk memperjuangkan hak-haknya sebagaimana yang diatur dalam UUPK. Salah

\footnotetext{
${ }^{1}$ Indonesia, Pasal 1 angka 1 Undang-Undang Nomor 21 Tahun 2011 tentang Otoritas Jasa Keuangan.
} 
satunya seperti di BPSK Provinsi DKI Jakarta yang menangani sengketa sebanyak 111 kasus (Tahun 2014) dan 121 kasus (Tahun 2015). ${ }^{2}$

Penanganan sengketa konsumen oleh BPSK bukan tanpa cela, karena tidak sedikit pelaku usaha yang mengeluhkan indepensi BPSK dalam menyelesaikan sengketa antara konsumen dan pelaku usaha. BPSK dinilai cenderung berpihak untuk melindungi konsumen dan dirasa belum memberikan penyelesaian yang memuaskan bagi pelaku usaha.

Kondisi demikian mendorong OJK untuk membentuk Lembaga Alternatif Penyelesaian Sengketa di Sektor Jasa Keuangan (LAPS-SJK) melalui Peraturan OJK Nomor 1 Tahun 2014. Dibentuknya LAPS-SJK didasari pertimbangan bahwa OJK ingin menyediakan lembaga alternatif penyelesaian sengketa yang secara khusus menangani sengketa yang terjadi antara konsumen dan pelaku usaha jasa keuangan.

Namun pembentukan LAPS-SJK ini seolah-olah ingin mengurangi kewenangan dari BPSK dalam menyelesaikan sengketa konsumen (khususnya sengketa antara konsumen dan pelaku usaha jasa keuangan). Bahkan hingga saat ini, tidak sedikit konsumen sektor jasa keuangan yang masih datang ke BPSK untuk meminta penyelesaian sengketa dan bukan datang ke LAPS-SJK.

Kondisi ini tentunya menunjukkan bahwa tujuan awal pembentukan LAPS-SJK belum tercapai, bahkan malah menimbulkan dualisme dalam penyelesaian sengketa antara konsumen di sektor jasa keuangan dan pelaku usaha jasa keuangan.

Melalui penelitian ini, Penulis ingin mendeskripsikan bahwa pembentukan LAPS-SJK belum menjadi solusi dalam penyelesaian sengketa antara konsumen di sektor jasa keuangan dan pelaku usaha jasa keuangan. Pembentukan LAPS-SJK malah menimbulkan dualisme dalam penyelesaian sengketa konsumen di sektor jasa keuangan.

\section{METODE PENELITIAN}

Penulis menggunakan metode penelitian hukum normatif, yaitu penelitian hukum yang meletakkan hukum sebagai sebuah bangunan sistem norma. ${ }^{3}$ Sifat dari penelitian ini adalah deskriptif analitis. ${ }^{4}$ Teknik pengumpulan data yang digunakan adalah dengan studi pustaka (library research) terhadap bahan-bahan hukum yang terdiri atas, bahan hukum primer, bahan hukum sekunder, dan bahan hukum tersier. Selain ketiga bahan hukum tersebut, juga digunakan bahan non hukum berupa hasil wawancara dengan Direktorat Perlindungan Hukum dan Konsumen Otoritas Jasa Keuangan, Badan Penyelesaian Sengketa Konsumen Provinsi DKI Jakarta, PT TOP Finance, PT Mitra Dana Putra Utama Finance, dan Badan Mediasi Pembiayaan dan Pegadaian Indonesia (BMPPI).

Metode analisis yang digunakan adalah metode analisis kualitatif. Metode ini digunakan untuk menganalisis dan mengeksplanasi hasil penelitian, dan kemudian menyajikan secara kualitatif. ${ }^{5}$ Selain itu, dalam menganalisis juga digunakan interpretasi gramatikal. ${ }^{6}$

${ }^{2}$ BPSK Provinsi DKI Jakarta, Rekapitulasi Jumlah Kasus yang ditangani oleh BPSK Provinsi DKI Jakarta Tahun 2014-2015, (Jakarta: BPSK Provinsi DKI Jakarta).

3 Mukti Fajar ND dan Yulianto Achmad, Dualisme Penelitian Hukumm Normatif dan Empiris, (Yogyakarta: Pustaka Belajar, 2010), hlm.34.

${ }^{4}$ Tundjung Herning Sitabuana, "Penyelesaian Masalah Diskriminasi Terhadap Etnis Cina (Studi Tentang Perkembangan Politik Hukum di Bidang Kewarganegaraan Republik Indonesia)", (Ringkasan Disertasi Doktor, Universitas Diponegoro, 2011), hlm.86.

${ }^{5}$ Ibid., hlm.94. 


\section{HASIL DAN PEMBAHASAN}

Pemerintah menyadari bahwa dalam dunia bisnis, kedudukan konsumen sangat lemah dan rentan untuk dijadikan sebagai obyek bisnis bagi pelaku usaha untuk meraup keuntungan yang sebesarbesarnya. Maka dari itu, pemerintah membuat regulasi guna melindungi kepentingan konsumen dari tindakan-tindakan pelaku usaha yang dapat merugikan konsumen, yaitu dengan diudangkannya UUPK.

Dengan keberadaan UUPK ini, diharapkan konsumen dapat menjadi lebih terlindungi dan pelaku usaha lebih memperhatikan hak-hak konsumen dalam menjalankan kegiatan usahanya. UUPK yang telah secara tegas menetapkan hak-hak konsumen diharapkan dapat menjadi pelecut bagi pelaku usaha untuk menjalankan usahanya dengan iktikad baik (good faith). ${ }^{7}$ Wirjono Prodjodikoro memberikan batasan iktikad baik dengan istilah "dengan jujur" atau "secara jujur". 8

Pemberlakuan UUPK juga sekaligus memberikan kesempatan bagi konsumen untuk menggugat pelaku usaha apabila merasa telah dirugikan atas tindakan pelaku usaha. gugatan tersebut dapat diajukan baik melalui pengadilan maupun di luar pengadilan.

Salah satu mekanisme penyelesaian sengketa di luar pengadilan yang disediakan adalah penyelesaian melalui BPSK. Dibentuknya BPSK merupakan mandat dari UUPK. Keberadaan BPSK diharapkan dapat menjadi solusi bagi konsumen yang merasa dirugikan untuk memperoleh perlindungan dan pertanggungjawaban hukum bagi pelaku usaha.

Penyelesaian sengketa konsumen melalui BPSK dirasa lebih memberikan kemudahan bagi konsumen daripada mekanisme penyelesaian sengketa di pengadilan negeri. Hal ini didasari pertimbangan bahwa mekanisme penyelesaian sengketa konsumen di BPSK relatif lebih singkat daripada mekanisme penyelesaian sengketa melalui pengadilan negeri. Sengketa konsumen yang diajukan ke BPSK harus diselesaikan dalam jangka waktu 21 (dua puluh satu) hari kerja, berbeda dengan penyelesaian sengketa melalui pengadilan negeri yang berlarut-larut.

Menurut ketentuan Pasal 52 huruf a jo. Pasal 4 Ayat (1) Keputusan Menteri Perindustrian dan Perdagangan Nomor 350 Tahun 2001, mekanisme penyelesaian sengketa konsumen yang disediakan oleh BPSK terdiri atas konsiliasi, mediasi, dan arbitrase. Hasil dari penyelesaian sengketa melalui konsiliasi dan mediasi akan dituangkan dalam bentuk perjanjian tertulis yang berisikan kesepakatan mengenai jenis dan besaran ganti rugi antara konsumen dan pelaku usaha. Untuk hasil dari penyelesaian sengketa melalui arbitrase akan dituangkan dalam bentuk suatu putusan arbitrase.

\footnotetext{
${ }^{6}$ Bambang Sutiyoso, Metode Penemuan Hukum (Upaya Mewujudkan Hukum yang Pasti dan Berkeadilan), (Yogyakarta: UII Press, 2012), hlm.111.

${ }^{7}$ Black's Law Dictionary memberi rumusan: "Good faith is an intangible and abstract quality with no technical meaning or statutory definition, and it compasses, among other things, an honest belief, the absence of malice and the absence of design to defraud or to seek an unconscionable advantage, and individual's personal good faith is concept of his own mind and inner spirit and, therefore, may not conclusively be determinded by his protestations alone. ... in common usage this term is ordinaryly used to describe that state of mind denoting honesty of purpose, freedom from intention to defraud, and, generally speaking, means being faithful to one's duty or obligation." Lihat: Henry Campbell Black, Black's Law Dictionary, (St. Paul Minnessota: West Publishing Co., 1990), hlm.693.

${ }^{8}$ Agus Yudha Hernoko, Hukum Perjanjian (Asas Proporsionalitas dalam Kontrak Komersial), (Jakarta: Kencana Prenada Media Group, 2014), hlm.134.
} 
Penyelesaian sengketa secara konsiliasi dan mediasi akan Ketiga mekanisme ini bersifat opsional/pilihan bagi konsumen dan pelaku usaha yang bersengketa di BPSK. Namun dalam implementasinya, ketiga mekanisme penyelesaian sengketa ini diterapkan secara berjenjang.

Penyimpangan penerapan ketiga mekanisme penyelesaian sengketa konsumen ini (yang seharusnya bersifat opsional, tapi diterapkan secara berjenjang) merupakan upaya BPSK untuk melindungi kepentingan konsumen. Karena jika mekanisme penyelesaian sengketa ini diterapkan secara opsional/pilihan, maka ketika tidak tercapainya kesepakatan mengenai bentuk dan besarnya ganti rugi antara konsumen dan pelaku usaha, maka sengketa tersebut tidak dapat diajukan kembali ke BPSK untuk diselesaikan, melainkan hanya dapat diajukan upaya keberatan ke pengadilan negeri. Selain itu, penerapan mekanisme penyelesaian sengketa secara berjenjang juga diharapkan dapat memperbesar peluang bagi para pihak untuk berdamai, sehingga tercapailah win-win solution. ${ }^{9}$

Dalam menyelesaikan sengketa antara konsumen dan pelaku usaha, BPSK mensyaratkan 2 (dua) hal, yaitu: (a) sengketa yang diajukan kepada BPSK harus merupakan sengketa antara konsumen akhir dan pelaku usaha; serta (b) adanya kerugian yang secara nyata (materiil) dialami oleh konsumen tersebut. Apabila ada sengketa yang tidak memenuhi kedua syarat tersebut, maka BPSK akan secara tegas menolak untuk menyelesaikan sengketa tersebut.

Dengan berpedoman pada kedua syarat tersebut, maka tidak sedikit gugatan konsumen yang diterima oleh BPSK untuk diselesaikan, termasuk sengketa antara konsumen dan pelaku usaha jasa keuangan (perbankan maupun non perbankan). Seperti beberapa contoh kasus yang didapati oleh Penulis saat berkunjung ke BPSK Provinsi DKI Jakarta, yaitu sengketa antara konsumen dan Bank Muamalat, serta sengketa antara konsumen dan PT Oscar Finance. Kedua contoh kasus tersebut merupakan sengketa yang melibatkan konsumen di sektor jasa keuangan dan pelaku usaha jasa keuangan.

Dengan dibentuknya LAPS-SJK, OJK bermaksud ingin menyediakan lembaga alternatif penyelesaian sengketa yang secara khusus menangani sengketa antara konsumen di sektor jasa keuangan dan pelaku usaha jasa keuangan. Namun dalam implementasinya, apa yang diharapkan oleh OJK masih jauh dari harapan. Masih terdapat banyak konsumen di sektor jasa keuangan yang mengajukan gugatan ke BPSK jika merasa dirugikan atas tindakan pelaku usaha jasa keuangan.

Pembentukan LAPS-SJK yang tidak disertai dengan adanya pengaturan yang tegas perihal kewenangan mengadili secara absolut merupakan faktor utama penyebab banyaknya sengketa konsumen di sektor jasa keuangan dan pelaku usaha jasa keuangan yang diterima oleh BPSK untuk diselesaikan. Selain itu, kurangnya sosialisasi kepada masyarakat mengenai keberadaan LAPS-SJK juga menjadi faktor penyebab lain.

Hingga tahun 2017, masih belum ada pengaturan yang tegas dan jelas perihal kewenangan mengadili secara absolut antara BPSK dan LAPS-SJK. Ketiadaan aturan ini menyebabkan dualisme dalam penyelesaian sengketa konsumen di sektor jasa keuangan. Kondisi ini terbukti dengan masih dimungkinkannya konsumen untuk mengajukan penyelesaian sengketa ke BPSK maupun ke LAPS-SJK.

\footnotetext{
${ }^{9}$ Aman Sinaga, wawancara dengan penulis, BPSK Provinsi DKI Jakarta, Jakarta, 9 Juni 2016.
} 


\section{KESIMPULAN DAN SARAN}

BPSK dibentuk sebagai lembaga alternatif penyelesaian sengketa konsumen di luar pengadilan. Dengan keberadaan BPSK, diharapkan dapat mengurangi penumpukan perkara antara konsumen dan pelaku usaha di pengadilan negeri. Hal ini dibuktikan dengan semakin meningkatnya jumlah perkara yang diselesaikan oleh BPSK dari tahun ke tahun (111 perkara di tahun 2014, dan 121 perkara di tahun 2015). ${ }^{10}$

Terkait dengan eksistensi BPSK, terdapat pihak-pihak yang kurang puas dengan kinerja BPSK dalam menyelesaikan sengketa konsumen, salah satunya adalah pelaku usaha jasa keuangan. Ketidakpuasan itu yang kemudian menjadi sebab pelaku usaha jasa keuangan mengusulkan kepada OJK untuk membentuk LAPS-SJK sebagai forum alternatif penyelesaian sengketa yang secara khusus menyelesaikan sengketa antara konsumen dan pelaku usaha jasa keuangan. Namun sayangnya pembentukan LAPS-SJK ini tidak disertai dengan pengaturan yang jelas dan tegas perihal kompetensi (kewenangan) mengadili secara absolut dari LAPS-SJK, sehingga sampai dengan saat ini masih banyak sengketa antara konsumen dan pelaku usaha jasa keuangan yang diselesaikan di BPSK.

Menurut hemat Penulis, kondisi ini tentunya menimbulkan dualisme dalam penyelesaian sengketa konsumen di sektor jasa keuangan, di mana konsumen yang merasa dirugikan atas tindakan pelaku usaha jasa keuangan dapat mengajukan gugatan ke BPSK maupun ke LAPSSJK. Selain menimbulkan dualisme, tentunya kondisi ini juga tidak memberikan kepastian hukum sebagaimana salah satu tujuan utama hukum di negara-negara yang menganut civil law system (termasuk Indonesia).

\section{Saran}

Berdasarkan uraian tersebut, maka menurut Penulis perlu adanya pengaturan yang jelas dan tegas mengenai kompetensi (kewenangan) mengadili secara absolut antara BPSK dan LAPS-SJK agar tidak menimbulkan dualisme dan memberikan kepastian hukum bagi konsumen dan pelaku usaha jasa keuangan.

\section{Ucapan Terimakasih}
a. Direktorat Perlindungan Hukum dan Konsumen Otoritas Jasa Keuangan Republik Indonesia;
b. Badan Penyelesaian Sengketa Konsumen Provinsi DKI Jakarta;
c. Badan Mediasi Pembiayaan dan Pegadaian Indonesia;
d. PT TOP Finance, Jakarta;
e. PT Mitra Dana Putra Utama, Jakarta;
f. Sugandi Ishak, S.H., M.H.

\section{REFERENSI}

Black, Henry Campbell. (1990). Black's Law Dictionary. West Publishing Co., St. PaulMinnessota.

Hernoko, Agus Yudha. (2014). Hukum Perjanjian (Asas Proporsionalitas dalam Kontrak Komersial). Kencana Prenada Media Group, Jakarta.

Indonesia. Undang-Undang Nomor 8 Tahun 1999 tentang Perlindungan Konsumen.

${ }^{10}$ BPSK Provinsi DKI Jakarta, Loc. Cit. 
Undang-Undang Nomor 21 Tahun 2011 tentang Otoritas Jasa Keuangan.

. Keputusan Menteri Perindustrian dan Perdagangan Republik Indonesia Nomor 350 Tahun 2001 tentang Pelaksanaan Tugas dan Wewenang Badan Penyelesaian Sengketa Konsumen.

- Peraturan Otoritas Jasa Keuangan Nomor 1 Tahun 2014 tentang Lembaga Alternatif Penyelesaian Sengketa di Sektor Jasa Keuangan.

ND, Mukti Fajar dan Yulianto Achmad. (2010). Dualisme Metode Penelitian Hukum Normatif dan Empiris. Pustaka Belajar, Yogyakarta.

Nugroho, Susanti Adi. (2011). Proses Penyelesaian Sengketa Konsumen Ditinjau dari Hukum Acara Serta Kendala Implementasinya. Kencana Prenada Media Group, Jakarta.

Shidarta. (2006). Hukum Perlindungan Konsumen Indonesia. Grasindo, Jakarta.

Sitabuana, Tundjung Herning. (2011). Penyelesaian Masalah Diskriminasi Terhadap Etnis Cina (Studi Tentang Perkembangan Politik Hukum di Bidang Kewarganegaraan Republik Indonesia). UNDIP, Semarang.

Sutiyoso, Bambang. (2012). Metode Penemuan Hukum (Upaya Mewujudkan Hukum yang Pasti dan Berkeadilan). UII Press, Yogyakarta. 